\title{
RESPON WARGA TERHADAP PERUBAHAN VISUAL DAN PERWUJUDAN IDENTITAS PEMUKIMAN WONOSARI MENJADI KAMPUNG PELANGI SEMARANG
}

\author{
Ernest Irwandi ${ }^{1}$, Setiawan Sabana ${ }^{2}$, Andryanto Rikrik Kusmara ${ }^{3}$, Tisna Sanjaya ${ }^{4}$ \\ $1,2,3,4$ Institut Teknologi Bandung \\ ernest.irw@gmail.com², setiawansabana@yahoo.com², twinrik@gmail.com³, tisnasanjaya@yahoo.com
}

\begin{abstract}
Abstrak
Satu dasawarsa ini, fenomena mewarnai kampung kota (urban villages) telah menjadi salah strategi berbagai kota di pulau Jawa untuk menciptakan daya tarik wisata. Kampung kota yang seringkali terkesan kumuh, menjelma sebagai kawasan wisata dan menjadi ikon kota. Penelitian ini dilakukan di pemukiman Wonosari Gunung Brintik, Semarang dan saat ini dikenal sebagai Kampung Pelangi. Sejak 2017, warna-warni Kampung Pelangi tidak hanya berfungsi sebagai penanda visual suatu lokasi, tetapi telah mengubah fungsi pemukiman menjadi kawasan wisata. Penelitian ini berupaya untuk mengetahui perubahan yang terjadi khususnya setelah pemukiman Wonosari dikenal sebagai Kampung Pelangi dan menjadi ikon baru bagi Kota Semarang. Penelitian ini menggunakan metode campuran, tahap pendataan awal dilakukan melalui wawancara, kemudian dilanjutkan dengan penyebaran kuesioner untuk mengetahui respon warga setempat terhadap perubahan visual pemukiman Wonosari menjadi Kampung Pelangi. Penelitian bertujuan untuk memahami bagaimana Kampung Pelangi mewujudkan identitas tempat melalui citra lokal serta mencari pendekatan model pemberdayaan terhadap potensi lokal sehingga berdampak pada keberlanjutan Kampung Pelangi sebagai destinasi wisata.
\end{abstract}

Kata kunci: citra visual, identitas Kampung Pelangi, place branding

\begin{abstract}
For almost a decade, coloring urban villages have become one of the strategies of various cities in Java to create a tourist attraction. The urban villages, that often considered slum areas had transformed to be tourist destinations and become an icon of cities. This research conducted in the settlement of Wonosari Gunung Brintik, Semarang, or now known as Kampung Pelangi. Since 2017, the colorful Kampung Pelangi has not only visually transformed a location but has transformed into a tourist destination. This research uses a mixed-method, collection of data conducted through interviews and questionnaires. This study uses the perspective of place identity and focuses on the residents' response to the visual changes of their settlement. This study also tries to understand the image construction process of place identity that represents its local values and search for an empowerment model that will impact the sustainability of Kampung Pelangi as a tourist destination.
\end{abstract}

Keywords: Kampung Pelangi's identity, place branding, visual image 


\section{PENDAHULUAN}

Setiap kota memiliki konsep pencitraan serta agenda pengembangannya guna menciptakan daya tarik wisata. Kotler (2004) pernah berpendapat, bahwa 'tempat adalah produk di mana identitas dan nilai-nilai dirancang dan dipasarkan sama halnya seperti sebuah produk'. Praktek 'memasarkan' sebuah kota sering dikenal dengan istilah city branding. Etimologi kata brand berasal dari bahasa Inggris kuno yang berarti 'burnt' atau 'terbakar'. Kata branding digunakan untuk menjelaskan suatu praktek yang telah dilakukan sejak pertengahan abad ke-17, yaitu memberi tanda kepemilikan pada suatu benda dengan cap besi panas. Kini pengertian branding dipahami tidak sekedar memberi tanda kepemilikan tetapi sebagai upaya merepresentasikan nila-nilai suatu produk atau jasa. Upaya representasi nilai-nilai dalam lingkup branding juga menggunakan pendekatan visual, yang dikenal sebagai identitas visual. Istilah identitas visual kerap ditemukan dalam ranah desain komunikasi visual, ranah strategi pemasaran dan manajemen korporasi. Menurut businessdictionary.com, identitas visual terdiri dari elemen-elemen yang terlihat dari suatu brand seperti warna, bentuk, gambar dan sebagainya dan elemen-elemen visual ini merangkum nilai serta karakterisitk suatu brand guna menyampaikan atau mengekspresikan makna simbolik suatu brand. Jika branding adalah upaya untuk memberi tanda kepemilikan terhadap sesuatu dan mengekspresikan makna, dalam konteks city branding atau place branding tujuan utamanya adalah untuk menciptakan keunikan yang menjadikan suatu kota berbeda dari yang lain. Menurut Kavaratzis (2004), tiga atribut utama yang mendasari city branding adalah: citra (image), keunikan (uniqueness) dan keaslian (authenticity).

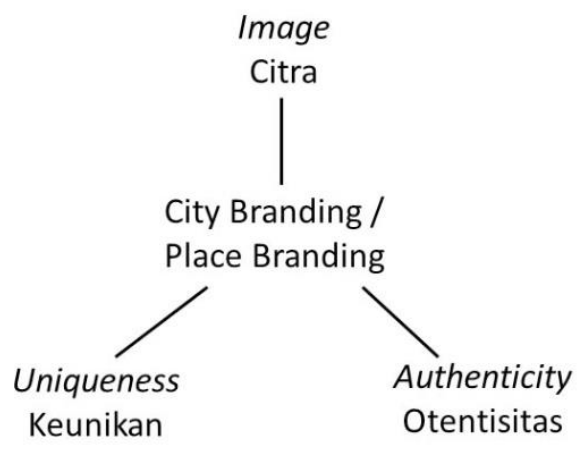

Gambar 1: Tiga atribut utama City Branding menurut Kavaratzis

[Sumber: Kavaratzis, 2004]

Sebelum membahas tentang bagaimana menciptakan citra visual sebuah kota dan merepresentasikan identitas kota, sepertinya perlu untuk memahami apa yang dimaksud dengan citra visual dan identitas. Secara umum citra visual adalah gambaran mental atau persepsi visual. Menurut ahli psikologi dan sejarah seni Rudolf Arnheim, suatu citra berfungsi sebagai stimulus, suatu teks, atau representasi yang menggerakkan proses kognisi, interpretasi, dan preferensi (Arnheim, 1977). Menurut Sandström (2007), citra visual adalah bagian dari struktur kognitif. Citra visual yang komprehensif diterima oleh manusia melalui indra penglihatan dan data visual digunakan untuk menghasilkan struktur makna di dalam pikiran. 
Pengertian citra dalam ranah branding adalah suatu representasi terhadap kualitas suatu produk atau jasa. Perancangan citra yang baik akan memperkuat memori akan suatu produk dan memberikan kesan mendalam kepada pemirsa (Stern dan Schroeder, 1994). Saat ini perwujudan makna suatu city brand telah beroperasi di luar kendali organisasi atau perusahaan manajemen pemasaran. Berikut adalah gambaran tentang perkembangan perspektif konstruksi makna city brand (Green, Grace dan Perkins, 2016).

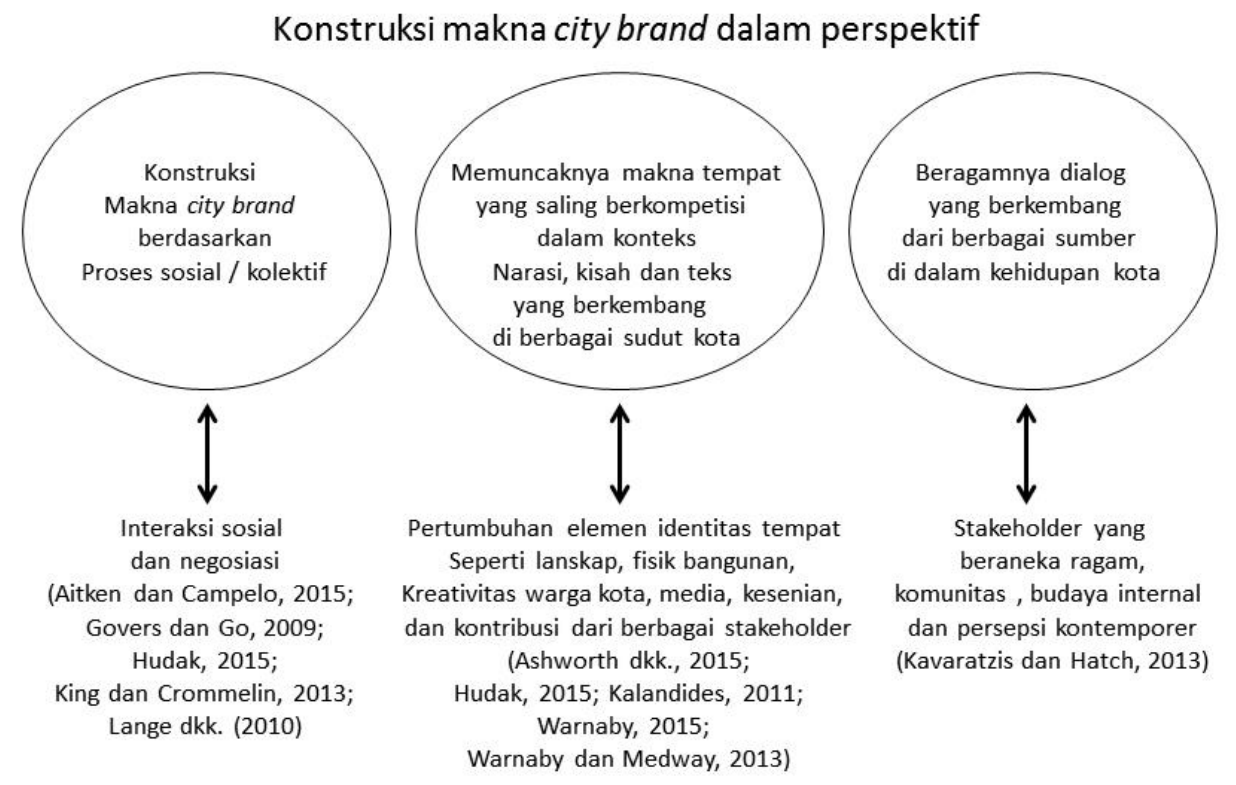

Faktor dan dorongan yang berkontribusi

Gambar 2. Pandangan progresif mengenai City Branding

[Sumber: Green, Grace, \& Perkins, 2016]

Menurut Skinner (2008) konstruksi makna city brand tidak dapat dipisahkan dari budaya kota. Menurut Ashworth makna city brand terwujud berdasarkan interaksi antar warga kota dari mulut ke mulut berdasarkan pengalaman langsung yang terjadi di kehidupan kota (Kavaratzis, 2015). Menurut Hornskov (2007), konstruksi makna city brand melalui media terus berkembang dan beradaptasi di dalam dialog masyarakat sehingga konstruksi makna bersifat organis. Hornskov juga berpendapat bahwa sejumlah kekuatan otonom seperti komunitas masyarakat lokal dan organisasi budaya secara independen berkontribusi pada konstruksi makna suatu kota. Stubbs dan Warnaby (2015) mengatakan bahwa perwujudan makna city brand saat ini mencakup berbagai dimensi dan bersifat kaleidoskopik.

Konstruksi makna suatu city brand terwujud dari rangkaian kekhasan suatu wilayah. Kekhasan suatu tempat selain terbentuk dari sejarah yang telah lama diinternalisasi, tetapi juga oleh hubungan konstelasi hubungan sosial, yang bertemu dan menjalin di lokus tertentu. Di dunia yang telah mengalami globalisasi, mobilitas budaya kian meningkat, akhirnya setiap tempat adalah tempat pertemuan unik yang dibangun oleh persilangan budaya. Meningkatnya mobilitas dan interaksi budaya juga meningkatkan imajinasi lokal sehingga mengubah perspektif tentang suatu tempat. 


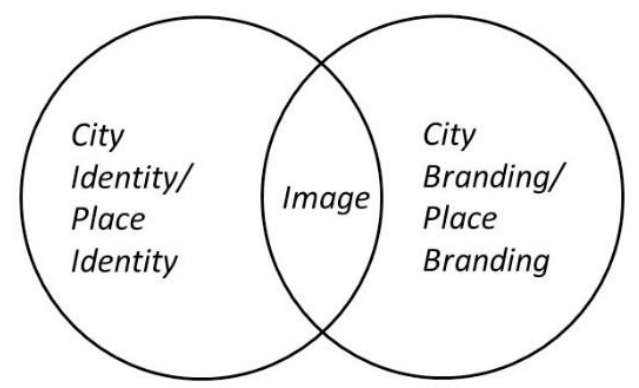

Gambar 3: Diagram relasi kualitas hidup dengan city branding

[Sumber: Riza, Doratli dan Fasli, 2011]

Sebagai pendekatan holistik, citra suatu kota atau tempat dapat dianggap sebagai salah komponen penting dalam perwujudan antara identitas kota dan city branding (Riza, Doratli dan Fasli, 2011). Walaupun city branding berfungsi sebagai alat promosi untuk menciptakan citra kota yang unik, namun langkah-langkah city branding harus memperhatikan aspek 'budaya, sejarah tempat, ekonomi, pembangunan sosial, infrastruktur, arsitektur, lanskap dan lingkungan; di mana seluruh aspek tersebut dapat dipadukan menjadi identitas yang dapat diterima oleh khalayak' (Zhang dan Zhao, 2009).

\subsection{Identitas Tempat}

Istilah identitas digunakan dalam berbagai disiplin ilmu dan merujuk pada suatu pengertian khusus dalam konteksnya. Definisi awal tentang identitas diutarakan oleh psikolog William James, yang menjelaskan tentang bagaimana manusia di dalam kesadarannya, melakukan pemisahan besar antara dunia 'Aku' dan dunia 'Bukan Aku' (Vignoles, 2017). Pemisahan ini kemudian mendorong diskusi tentang identitas individu dan identitas sosial. Pengertian identitas sosial dimulai dengan premis bahwa individu mendefinisikan identitas diri dengan memperhatikan kelompok sosial dan mengidentifikasikan bahwa ia adalah bagian dari kelompok tertentu (Tajfel, 1978). Pengertian lain, bahwa identitas dipersonalisasikan pada keanggotaan kelompok tertentu dari kategori sosial yang sama (Adler, 2009). Identitas sosial sebagai 'extended self' dari identitas personal. Keterkaitan identitas individu, identitas sosial dengan suatu tempat dikenal dengan istilah identitas tempat atau place identity.

Salah satu fokus studi di dalam psikologi lingkungan dan arsitektur, yang mempelajari fenomena ikatan masyarakat terhadap suatu tempat, dikenal sebagai sense of place study. Spektrum fenomena yang dipelajari antara lain: identitas tempat (place identity), keterikatan terhadap tempat (place attachment), keber-akar-an (rootedness) dan kepuasan (satisfaction) terhadap suatu tempat (Kaltenborn, 1998). Dalam ranah studi tata kota dan arsitektur, para ahli memiliki berbagai penjelasan mengenai studi interaksi manusia terhadap suatu tempat. Salah satu pandangan adalah dengan melihat sense of place berdasarkan empat sistem: kecenderungan biologis, fitur lingkungan, perkembangan psikologis, dan proses sosiokultural. Dari sudut pandang ini, sense of place terbentuk melalui proses interaksi dengan lingkungannya terkait keempat sistem ini (Altman dan Low, 1992). 
Tabel 1. Interaksi antara manusia dengan tempat meliputi tiga dimensi

[Sumber: Altman dan Low, 1992]

\begin{tabular}{|c|c|c|c|}
\hline \multirow{4}{*}{$\begin{array}{c}\text { Interaksi antara } \\
\text { manusia dan } \\
\text { tempat }\end{array}$} & Tipe relasi & & Komponen tempat \\
\hline & Kognitif & $\begin{array}{l}\text { Persepsi umum untuk memahami } \\
\text { geometri ruang dan orientasi }\end{array}$ & Wujud (Form) \\
\hline & Perilaku & $\begin{array}{l}\text { Persepsi kemampuan ruang untuk } \\
\text { menghadirkan ragam Kebutuhan }\end{array}$ & Fungsional \\
\hline & Emosional & $\begin{array}{l}\text { Persepsi kepuasan dan keterikatan } \\
\text { pada Tempat }\end{array}$ & Makna \\
\hline
\end{tabular}

Secara umum, interaksi antara manusia dengan tempat, terjadi dalam tiga dimensi yaitu: kognitif, perilaku dan emosional. Aspek kognitif mengarah pada persepsi spasial di mana seseorang mengenal suatu lingkungan dan pengetahuan itu digunakan untuk menavigasi dan bergerak di suatu ruang. Aspek perilaku berkaitan dengan hubungan fungsional antara manusia dengan lingkungannya di mana seseorang dapat melakukan aktivitasnya. Aspek emosional terhadap tempat merujuk pada kepuasan dan keterikatan terhadap tempat. Relasi antara ketiga faktor ini bisa sangat kuat sehingga menciptakan ikatan erat antara individu dengan suatu tempat. Dalam hal ini, pengalaman perseptual seseorang terhadap suatu tempat adalah faktor yang sangat menentukan keterikatan terhadap tempat. Seperti disebutkan dalam tabel di atas, relasi kognisi merujuk pada aspek formal suatu tempat. Relasi perilaku merujuk pada aspek fungsional atau ragam kegiatan yang dapat dilakukan pada suatu lingkungan. Sedangkan relasi emosi terhadap suatu tempat berkaitan dengan makna suatu tempat pada seseorang.

Menurut Proshansky (1983), interaksi manusia terhadap tempat menghasilkan interpretasi terhadap suatu tempat dan menghasilkan keterikatan (attachment) terhadap suatu tempat. Keterikatan ini terjalin antara identitas individu dengan tempatnya dimana identitas tumbuh sejak anak-anak dan berkembang ketika anak-anak belajar melihat diri mereka di dalam konteks lingkungannya. Identitas individu berakar pada ingatan tentang rumah, kamar, pakaian lingkungan tempat bermain dan belajar. Perubahan identitas tempat berlangsung sepanjang hidup seseorang. Pengertian identitas tempat menurut Proshansky adalah, komponen sistem yang merujuk pada cara seseorang memandang dirinya dalam kaitannya dengan lingkungannya (Smaldone, Harris dan Sanyal, 2008). Diskusi mengenai identitas tempat juga mencakup struktur identitas sosial, kelas sosial, ingatan kolektif dan nilai-nilai yang dianut oleh sekelompok masyarakat .

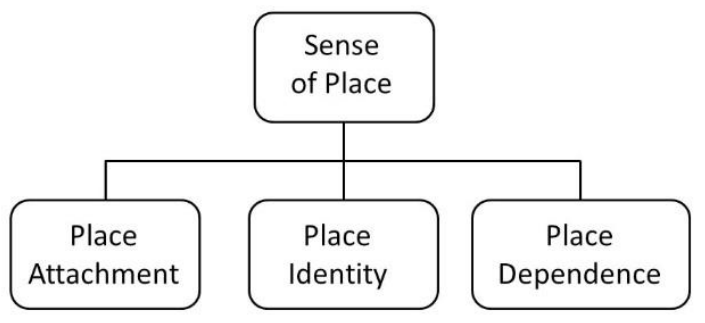

Gambar 4. Model Place Attachment

[Sumber: Hernandez, Hidlago dan Ruiz, 2014] 
Jorgensen dan Stedman (2001) mengusulkan bahwa faktor place attachment, place dependence dan place identity sebagai bagian dari dimensi sense of place. Pengertian place attachment adalah hubungan emosional seseorang terhadap tempat atau pada situs fisik dan makna terbentuk melalui interaksi antara individu dengan tempatnya (Manzo dan Devine, 2014). Sedangkan place dependence dikonseptualisasikan sebagai peluang-peluang yang tercipta karena pengaturan suatu tempat untuk aktivitas manusia dalam rangka memenuhi kebutuhannya (Stokols dan Shumaker, 1981). Ketiga faktor ini dapat memberikan informasi mengenai persepektif seseorang dan hubungannya dengan kondisi publik tertentu (Manzo dan Devine, 2014).

\subsection{Perubahan Pemukiman Wonosari menjadi Kampung Pelangi}

Fenomena menghias kampung dengan warna-warni mural telah berkembang pesat satu dasawarsa ini, khususnya di kampung kota di Pulau Jawa. Kampung Pelangi di Semarang adalah salah satu contoh kampung di tengah kota atau dikenal sebagai urban villages, yang mengalami proses perubahan sebagai akibat dari modernisasi kota Semarang. Sebelum dikenal dengan nama Kampung Pelangi, nama pemukiman adalah Wonosari, Kecamatan Randusari. Luas pemukiman Wonosari -/+ 4 ha dan terdiri dari dua wilayah RW yaitu RW03 dan RW04. Wilayah pemukiman Wonosari telah ada sejak lama dan sepanjang sejarahnya telah memiliki empat nama; pertama adalah Bergota, kemudian dikenal juga sebagai wilayah Gunung Brintik, hingga saat ini tercatat resmi sebagai wilayah Wonosari dan sekarang dikenal sebagai Kampung Pelangi.

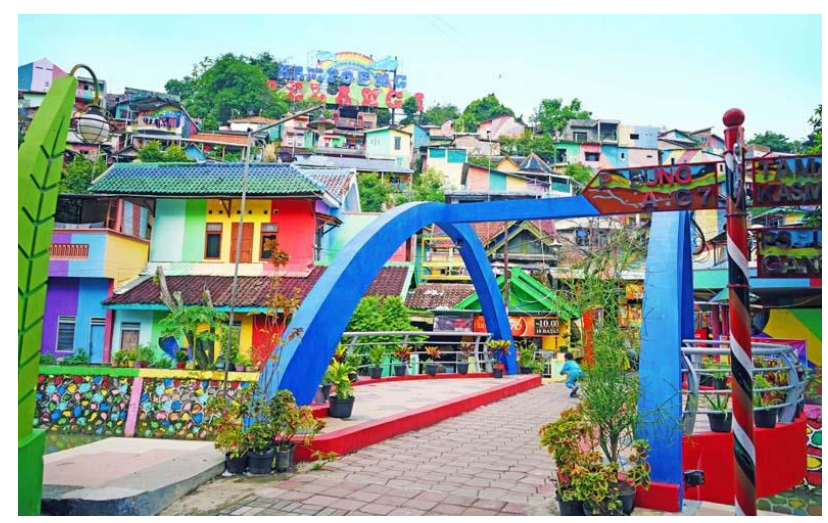

Gambar 5. Jembatan menuju ke Kampung Pelangi, Kota Semarang [Sumber: Dokumentasi Penulis, 2019]

Berdasarkan penelusuran literatur tentang Kampung pelangi Semarang, pada Tahun 1985 wilayah Wonosari Gunung Brintik mengalami pemekaran wilayah, sejak itu para pendatang mulai memanfaatkan lahan kosong dan menetap di sana. Karena posisi Wonosari Gunung Brintik dekat dengan pusat kota dan harga sewa tanah yang cukup murah, banyak orang mulai berdatangan dan menyewa tanah serta membangun rumah. Lambat laun wilayah Wonosari Gunung Brintik menjadi sebuah pemukiman dengan nama Wonosari. Di sekeliling pemukiman Wonosari mulai diramaikan oleh pedagang sayur, buah, bunga dan lain-lain. Seperti yang dikutip dari Saraswati dan Nestri, bahwa pada tahun 1998 Indonesia mengalami krisis moneter yang berdampak pada penduduk di wilayah Wonosari. Pedagang yang tinggal di wilayah Wonosari menghadapi kesulitan 
ekonomi, akhirnya beberapa memutuskan untuk kembali ke kampung halaman, bagi yang menetap harus berjuang keras untuk mencari nafkah (Saraswati dan Nestri, 2017).

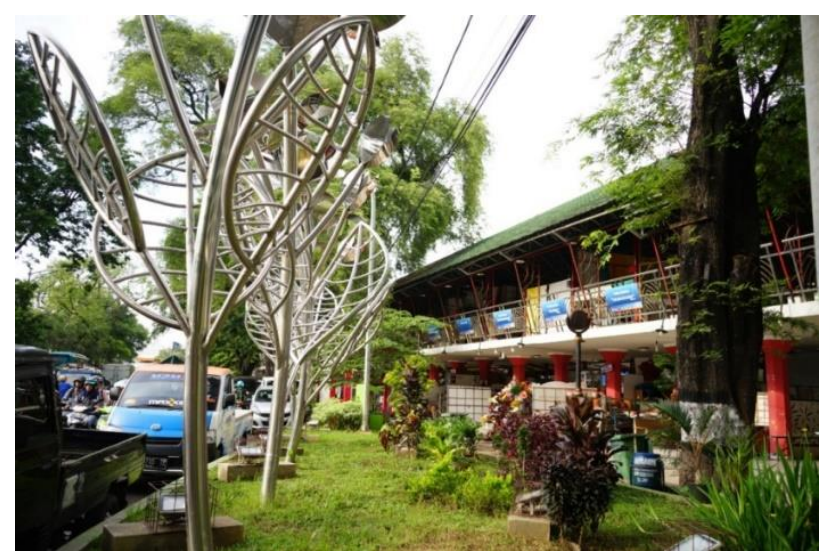

Gambar 6. Pasar Bunga Kalisari

[Sumber: Dokumentasi Penulis, 2019]

Berdasarkan data wawancara bersama dengan Bapak Fajar ketua RW04 pada tanggal 6 April, 24 dan 25 November 2019, diperoleh informasi bahwa awal jadinya Kampung Pelangi adalah pada tahun 2017 ketika pemerintah Kota Semarang melakukan penataan Pasar Bunga Kalisari di depan pemukiman Wonosari. Setelah penataan Pasar Bunga Kalisari selesai, dilakukan juga penataan pemukiman Wonosari yang terletak tepat dibelakang pasar bunga Kalisari, hal ini dilakukan oleh pemerintah kota agar wajah Pasar Bunga dan Kampung menjadi indah dan dapat menarik wisatawan. Dana penataan wilayah diperoleh dari Gabungan Pengusaha Nasional Indonesia dan kebanyakan perusahaan dari Jawa Tengah.

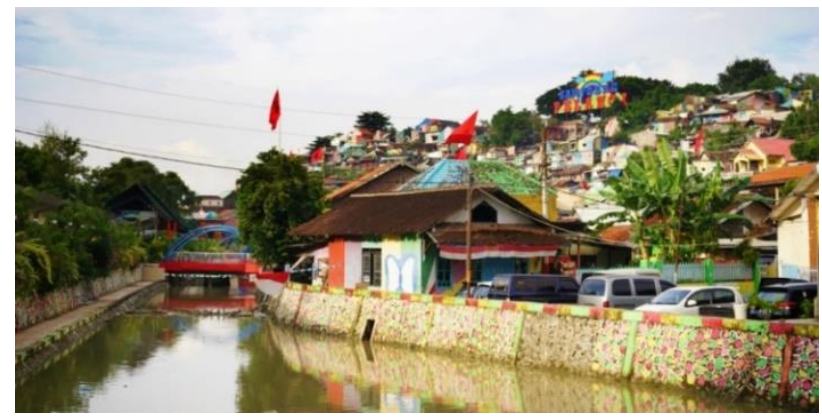

Gambar 7. Kampung Pelangi di belakang Pasar Kalisari

[Sumber: Penulis 2019]

Sejak bulan Mei 2017, Kampung Wonosari telah menjadi ikon wisata baru di Kota Semarang, yang diberikan nama Kampung Pelangi. Seperti yang dikutip dari Adiwibawa \& Prabowo (2018) bahwa bangunan ikonik kota adalah bangunan yang terkenal atau dikenal baik oleh masyarakat Kota Semarang dan atau dari luar Kota Semarang sebagai bagian dari arsitektur kota. Bangunan ikonik dapat merupakan bangunan pusaka budaya kota, atau bangunan baru. Walaupun bangunan Kampung Pelangi berupa hunian dan bukan bangunan baru tetapi warna-warni yang diterapkan telah mengubah fasad pemukiman. Keindahan Kampung Pelangi terletak pada kontur tanah bukit, sehingga 
warna-warni pemukiman pada tanah berundak menghasilkan sensasi visual yang unik. Namun dengan segala perubahan visual yang telah terwujud bagaimana dampak perubahan yang dialami oleh warga setempat? Penelitian ini berupaya untuk memahami sense of place menurut perspektif warga yang meliputi: pertama place identity, kedua terkait dengan keterikatan terhadap suatu tempat atau place attachment, dan ketiga terkait dengan rasa ketergantungan dengan suatu tempat atau place dependence di Kampung pelangi Semarang. Selain respon warga, penelitian juga didukung dengan data observasi lapangan khususnya terkait dengan perubahan visual yang terjadi di kampung pelangi.

\section{METODE PENELITIAN}

Pengumpulan data ini adalah tahap awal dari penelitian tentang Place Branding dengan pendekatan partisipatori. Pengumpulan data dalam tahap ini akan digunakan untuk tahap penelitian selanjutnya yaitu untuk mengidentifikasi, eksplorasi dan memberdayakan potensi lokal. Tahap akhir dari rangkaian penelitian ini fokus pada penciptaan Place Branding dengan pendekatan partisipatori. Berikut adalah tahap penelitian dari pengumpulan data awal hingga menuju perencanaan tahap Place Branding.

Tabel 2. Tahap penelitian

[Sumber: Dokumentasi penulis, 2020]

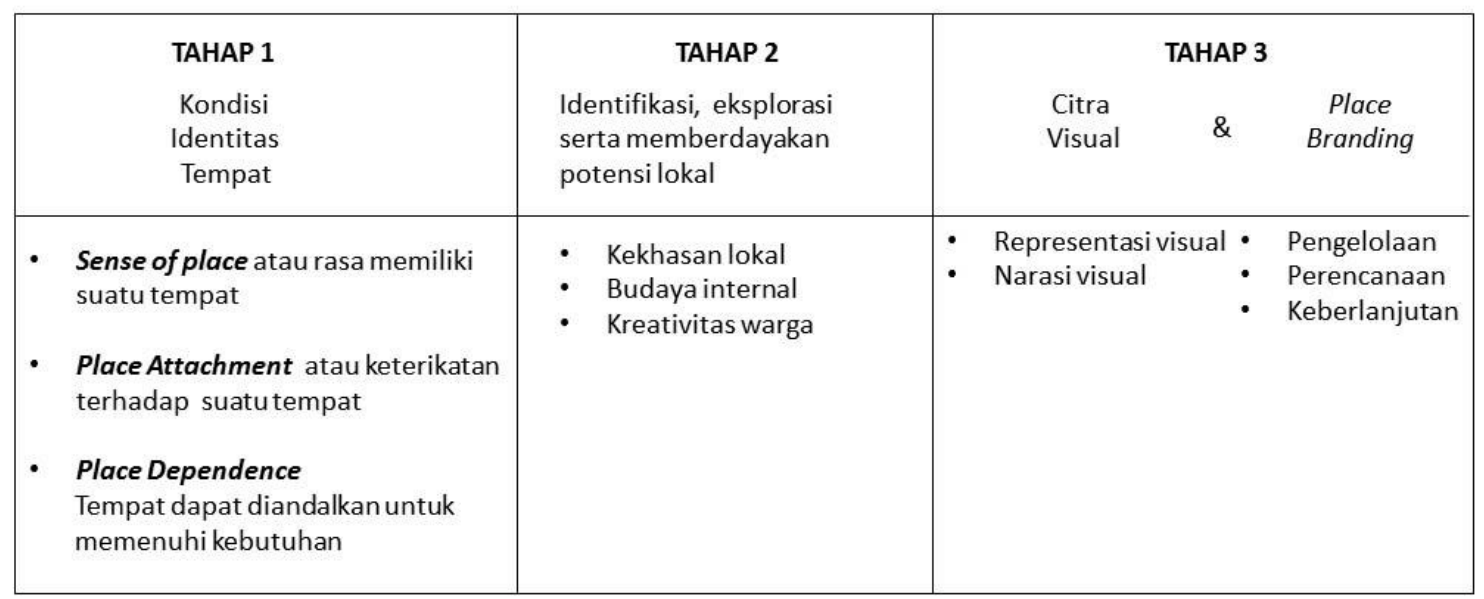

Pengumpulan data dilakukan melalui wawancara dan kuesioner yang dirancang untuk memperoleh data tentang persepsi warga terhadap dampak perubahan setelah menjadi Kampung Pelangi. Berdasarkan 3 faktor yang mengikuti model sense of place yaitu: Place Identity, Place Attachment dan Place Dependence, maka kuesioner dalam penelitian ini dirancang seperti tabel di bawah ini.

Tabel 3. Deskripsi Place Identity, Place Atatchment dan Place Dependence

[Sumber: Dokumentasi penulis, 2020]

\begin{tabular}{|c|c|l|}
\hline Faktor & Label & \multicolumn{1}{c|}{ Deskripsi } \\
\hline Place Identity & I-1 & Kebanggaan terhadap suatu tempat. \\
\cline { 2 - 3 } & I-2 & Suatu tempat mencerminkan ekspresi warga. \\
\cline { 2 - 3 } & I-3 & Suatu tempat banyak menyimpan kenangan. \\
\hline
\end{tabular}




\begin{tabular}{|c|c|c|}
\hline Faktor & Label & Deskripsi \\
\hline \multirow[t]{5}{*}{ Place Attachment } & A-1 & $\begin{array}{l}\text { Adanya kerinduan terhadap suatu tempat jika bepergian } \\
\text { jauh. }\end{array}$ \\
\hline & $A-2$ & $\begin{array}{l}\text { Merasa suatu tempat lebih nyaman sebelum/setelah } \\
\text { dilakukan penataan. }\end{array}$ \\
\hline & A-3 & $\begin{array}{l}\text { Merasa tempat lebih bersih sebelum/setelah dilakukan } \\
\text { penataan. }\end{array}$ \\
\hline & $A-4$ & Sering / jarang berkumpul di suatu tempat. \\
\hline & A-5 & $\begin{array}{l}\text { Suatu tempat memiliki nilai-nilai yang tidak dapat } \\
\text { ditemukan di tempat lain. }\end{array}$ \\
\hline \multirow[t]{5}{*}{ Place Dependence } & D1 & Segala kebutuhan tersedia di suatu tempat. \\
\hline & D2 & $\begin{array}{l}\text { Merasa terganggu atau tidak dengan perubahan yang ada } \\
\text { di suatu tempat. }\end{array}$ \\
\hline & D3 & $\begin{array}{l}\text { Beraktivitas dan menghabiskan waktu lama di suatu } \\
\text { tempat. }\end{array}$ \\
\hline & D4 & $\begin{array}{l}\text { Terlibat kegiatan untuk selalu menjaga kebersihan suatu } \\
\text { tempat. }\end{array}$ \\
\hline & D5 & $\begin{array}{l}\text { Ingin terlibat jika ada kegiatan yang membuat suatu } \\
\text { tempat lebih baik. }\end{array}$ \\
\hline
\end{tabular}

Jumlah populasi ditetapkan berdasarkan jumlah rumah yang telah ditata pada tahap awal penataan Kampung Pelangi di tahun 2017. Menurut data wawancara bersama dengan Ketua RW04 Bapak Fajar, jumlah rumah yang ditata pada tahun 2017 mencapai 300 rumah. Jumlah sampling sementara ditentukan $10 \%$ dari jumlah pemilik rumah, maka jumlah sampel adalah 30 sampel.

\section{HASIL DAN PEMBAHASAN}

Data diperoleh melalui penyebaran kuesioner dan wawancara kepada 30 warga Kampung Pelangi RW03 dan RW04, dengan latar belakang responden $60 \%$ adalah perempuan dengan rentang usia antara 45 hingga 65 tahun, $20 \%$ anak-anak laki-laki dan perempuan dengan rentang usia sekolah 13 hingga 16 tahun, dan 20\% adalah laki-laki dengan rentang usia 40 hingga 65 tahun. Selain data yang diperoleh dari kuesioner, data juga diperoleh melalui wawancara mendalam kepada beberapa warga di Kampung Pelangi guna memahami pendapat warga.

Tabel 4. Hasil kuesioner

[Sumber: Dokumentasi penulis, 2020]

\begin{tabular}{|c|c|c|l|}
\hline No & Label & \multicolumn{1}{|c|}{ Responden } & \multicolumn{1}{c|}{ Hasil Kuisioner } \\
\hline 1 & I-1 & 30 dari 30 responden & Merasa bangga tinggal Kampung Pelangi. \\
\hline 2 & I-2 & 29 dari 30 responden & $\begin{array}{l}\text { Merasa warna-warninya kampung mewakili ekspresi } \\
\text { keceriaan warga. }\end{array}$ \\
\hline 3 & I-3 & 20 dari 30 responden & Memiliki banyak kenangan di Kampung Pelangi. \\
\hline 4 & A-1 & 30 dari 30 responden & $\begin{array}{l}\text { Merasa rindu untuk kembali ke Kampung Pelangi } \\
\text { ketika bepergian jauh. }\end{array}$ \\
\hline 5 & A-2 & 27 dari 30 responden & $\begin{array}{l}\text { Merasa kampung lebih nyaman setelah menjadi } \\
\text { Kampung Pelangi. }\end{array}$ \\
\hline
\end{tabular}




\begin{tabular}{|c|c|c|l|}
\hline No & Label & \multicolumn{1}{|c|}{ Responden } & \multicolumn{1}{|c|}{ Hasil Kuisioner } \\
\hline 6 & A-3 & 30 dari 30 responden & $\begin{array}{l}\text { Merasa kampung lebih bersih setelah menjadi } \\
\text { Kampung Pelangi. }\end{array}$ \\
\hline 7 & A-4 & 18 dari 30 responden & Sering berkumpul di Kampung Pelangi. \\
\hline 8 & A-5 & 30 dari 30 responden & $\begin{array}{l}\text { Kampung Pelangi memiliki nilai-nilai yang tidak dapat } \\
\text { ditemukan di tempat lain }\end{array}$ \\
\hline 9 & D1 & 30 dari 30 responden & Merasa segala kebutuhan tersedia di Kampung Pelangi \\
\hline 10 & D2 & 30 dari 30 responden & $\begin{array}{l}\text { Tidak merasa terganggu dengan banyaknya } \\
\text { pengunjung, justru merasa senang }\end{array}$ \\
\hline 11 & D3 & 18 dari 30 responden & $\begin{array}{l}\text { Beraktivitas dan menghabiskan waktu lama di } \\
\text { Kampung Pelangi. }\end{array}$ \\
\hline 12 & D4 & $\begin{array}{l}24 \text { dari } 30 \\
\text { responden }\end{array}$ & $\begin{array}{l}\text { Terlibat kegiatan kerja bhakti untuk selalu menjaga } \\
\text { kebersihan kampung. }\end{array}$ \\
\hline 13 & D5 & 30 dari 30 responden & $\begin{array}{l}\text { Ingin terlibat jika ada kegiatan yang membuat } \\
\text { kampung lebih baik. }\end{array}$ \\
\hline
\end{tabular}

Melalui data yang diperoleh berdasarkan penyebaran kuesioner, wawancara dengan warga dan observasi lapangan di Kampung Pelangi pada tanggal 6 April, 24 dan 25 November 2019, maka pemaparan hasil yang diperoleh sebagai berikut:

\section{A. Respon warga terhadap perubahan pemukiman Wonosari menjadi Kampung Pelangi.}

Berdasarkan data kuesioner dan wawancara, mayoritas warga merasa kampung lebih nyaman dan lebih bersih setelah menjadi Kampung Pelangi. Sejak penataan di tahun 2017 hingga saat ini, perbaikan masih terus dilakukan secara berkala baik oleh pemerintah kota, oleh berbagai stakeholder dan oleh warga Kampung Pelangi. Pemberitaan tentang wisata ke Kampung Pelangi Semarang juga sempat viral di media sosial dan hal ini membuat warga merasa bangga karena tempat tinggalnya dikenal sebagai kawasan wisata. Sejak menjadi Kampung Pelangi, banyak pengunjung yang datang namun warga tidak merasa keberatan dengan keramaian di Kampung Pelangi. Beberapa warga banyak menghabiskan waktu di Kampung Pelangi karena telah membuka usaha kecil di wilayah Kampung Pelangi. Karena sering dikunjungi, maka warga ingin selalu mempertahankan kebersihan Kampung dan kegiatan kerja bhakti juga sering dilakukan.

\section{B. Perubahan visual pemukiman.}

Penataan Kampung Pelangi dimulai pada tahun 2017 dan pada tahap awal dinding pada ruang umum seperti jembatan dan tembok pembatas serta dinding 300 rumah warga diwarnai dengan cat warna-warni. Perbaikan juga dilakukan pada aliran air dan sungai di depan Kampung Pelangi. 
Tabel 5. Analisis visual di Kampung Pelangi

[Sumber: Dokumentasi penulis, 2020]

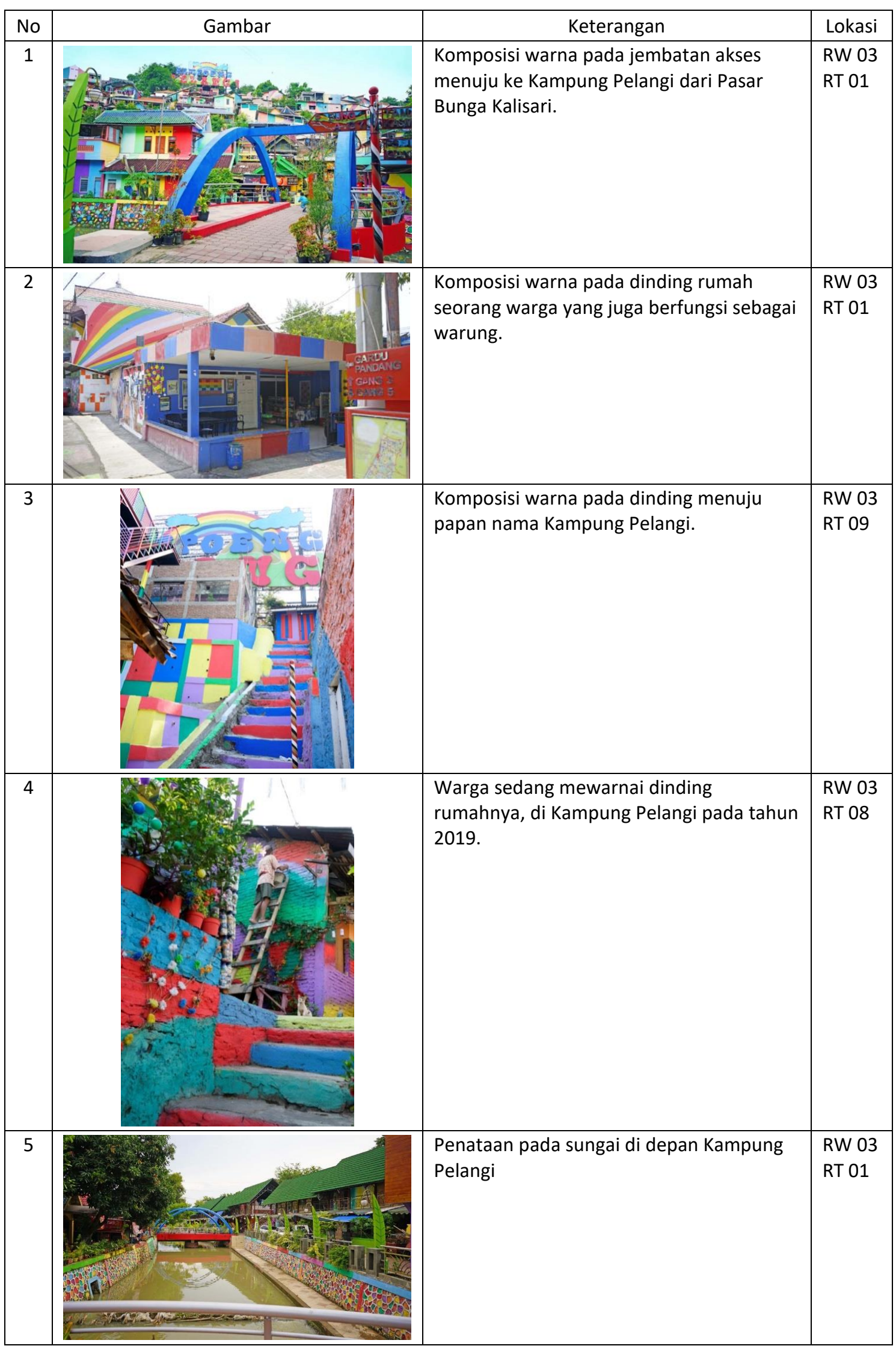


Sejak penataan 2017, penataan juga masih dilakukan secara berkala. Selain dinding rumah dan ruang umum yang ditata, didirikan juga penanda visual sebagai identifikasi kampung. Papan nama Kampung Pelangi yang besar dipasang di tingkat teratas bukit sebagai penanda visual.

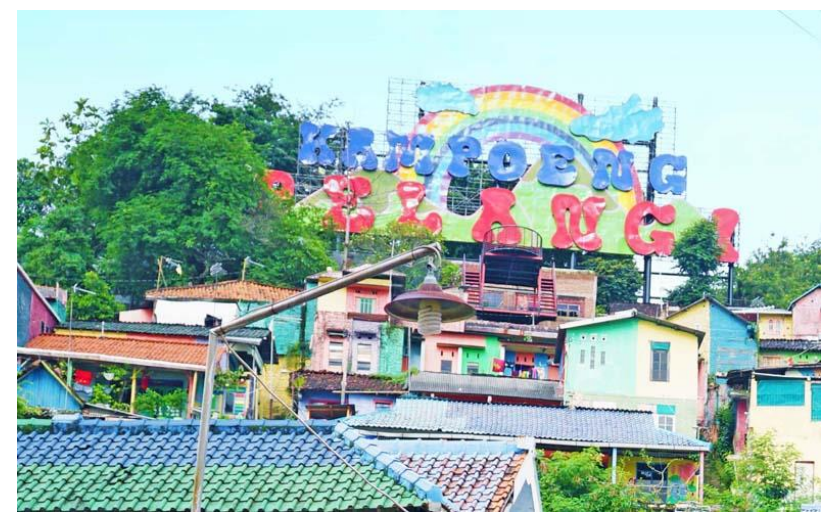

Gambar 8. Papan nama Kampung Pelangi

[Sumber: Dokumentasi penulis, 2020]

Pada posisi atas tulisan "Kampoeng Pelangi' terdapat visual pelangi dan awan, yang membuat komposisi visual seperti konfigurasi pada logo suatu tempat wisata.
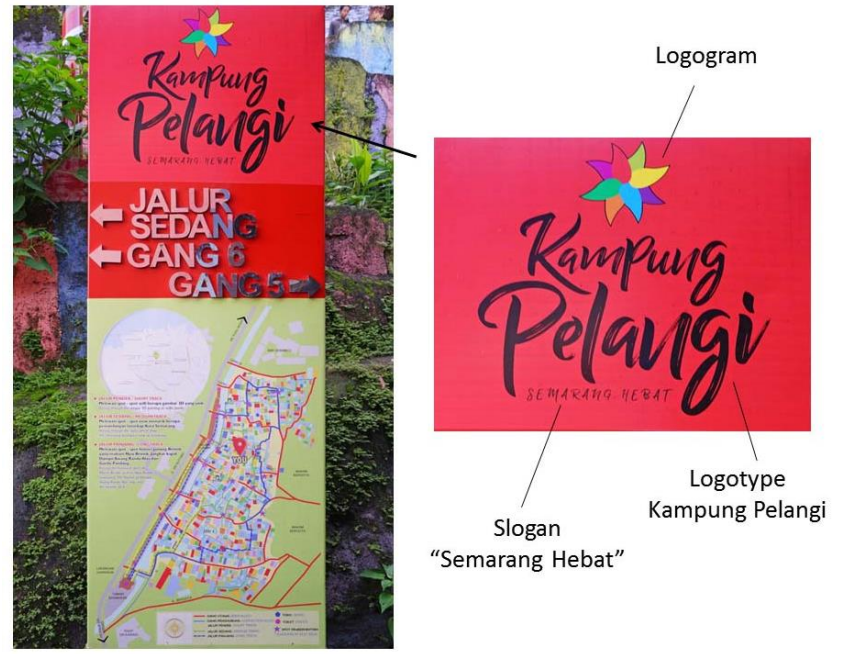

Gambar 9. Papan penunjuk arah dan peta di Kampung Pelangi [Sumber: Dokumentasi penulis, 2020]

Jika kita berjalan masuk ke Kampung Pelangi kita dapat menemukan papan penunjuk arah. Jika dicermati pada bagian atas peta, terdapat tulisan kampung pelangi yang dibuat seperti konfigurasi sebuah desain logo di mana elemen visual terdapat kombinasi antara logogram, logotype dan slogan. 


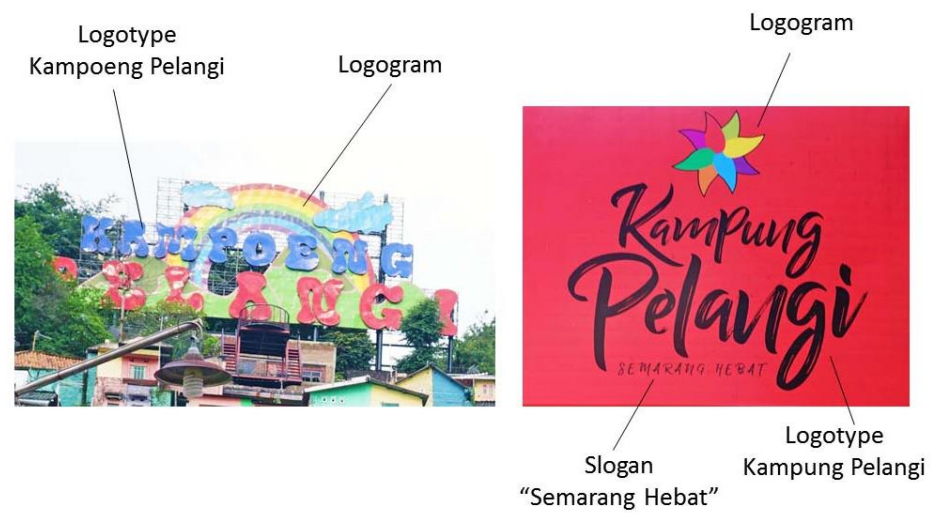

Gambar 10. Perbedaan desain pada papan nama dengan papan penunjuk arah di Kampung Pelangi

[Sumber: Dokumentasi penulis, 2020]

Hal yang menarik adalah tulisan kampung pelangi pada papan nama kampung menggunakan ejaan lama bahasa indonesia yaitu 'Kampoeng', sedangkan pada papan penunjuk arah menggunakan kata "Kampung". Visual logogram padap papan penunjuk arah adalah bunga dengan 8 kelopak yang berwarna-warni bukan pelangi seperti pada papan nama Kampoeng Pelangi. Penerapan konfigurasi visual di kedua papan nama dan papan penunjuk arah, seolah desain terdapat dua versi yang tidak berkesinambungan.

\section{Keterlibatan Stakeholder}

Berdasarkan data wawancara bersama dengan Ketua RW 04 Bapak Fajar, diperoleh data bahwa penataan Kampung Pelangi melibatkan banyak stakeholder antara lain: pemerintah kota, perusahaan, institusi pendidikan, komunitas kreatif di kota Semarang dan komunitas warga Kampung Pelangi.

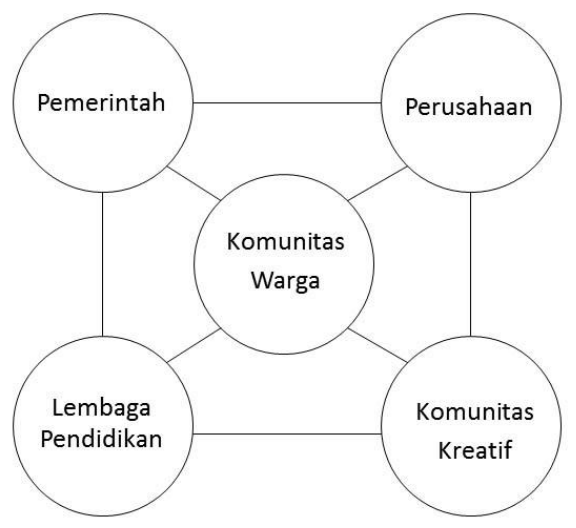

Gambar 11. Stakeholder dalam penataan Kampung pelang

[Sumber: Dokumentasi penulis, 2020]

Perubahan kampung telah mendorong peningkatan jumlah stakeholder sejak 2017 dan berbagai bentuk pengembangan di Kampung Pelangi telah banyak dilakukan seperti program penataan kampung secara berkala, pemberdayaan warga dalam bentuk pelatihan-pelatihan dan penyelenggaraan event-event yang dapat menarik wisatawan. Berdasarkan data-data di atas maka diketahui bahwa interaksi baik warga setempat dan 
pengunjung Kampung Pelangi terjalin dalam tiga dimensi kognitif, perilaku dan emosional. Seperti yang dikemukakan oleh Altman dan Low bahwa dimensi kognitif mengarah pada persepsi spasial di mana seseorang mengenal suatu lingkungan, dan relasi antara manusia dengan tempatnya merujuk pada aspek formal suatu tempat. Relasi antara ketiga faktor ini bisa sangat kuat sehingga menciptakan ikatan erat antara individu dengan suatu tempat. Dalam hal ini, pengalaman perseptual seseorang terhadap suatu tempat adalah faktor yang sangat menentukan keterikatan terhadap tempat (Ram, Björk dan Weidenfeld, 2016).

Aspek formal yang sangat jelas terlihat pada Kampung Pelangi adalah elemen warna. Warna-warni rumah memenuhi kontur tanah Kampung Pelangi yang berbukit sehingga secara drastis menciptakan perubahan visual yang membedakannya dengan lingkungan sekitar. Dari kejauhan warga dan pengunjung dengan mudah mengenal posisi Kampung Pelangi sehingga memudahkan navigasi menuju Kampung Pelangi. Warna tidak hanya berfungsi untuk identifikasi ruang tetapi juga menciptakan aspek fungsional lainnya. Pada dimensi perilaku, warga setempat melihat aspek fungsional ketika tempatnya menjadi kawasan wisata dan warga memanfaatkan peluang itu untuk berdagang dan melakukan ragam kegiatan kreatif lainnya guna menarik wisatawan. Selain itu warnawarni Kampung mengubah perilaku warga untuk selalu menjaga kebersihan lingkungannya. Sedangkan pada dimensi emosional, berdasarkan data kuesioner dan wawancara, pengunjung dan warga melihat warna-warni Kampung Pelangi mewakili keceriaan dan keberagaman yang ada.

Namun ikatan emosional dengan tempat yang dialami oleh warga telah terjalin lama. Banyak warga memiliki kenangan di Kampung Pelangi karena sebagian besar responden lahir dan bertumbuh di Kampung Pelangi sehingga place attachment dapat disebabkan karena adanya ikatan komunitas yang erat dan telah terjadi sejak lama, bahkan sebelum berubah sebagai Kampung Pelangi. Hal ini menunjukan bahwa keterikatan ini terjalin antara identitas individu dengan tempatnya di mana identitas tumbuh sejak anak-anak dan berkembang ketika anak-anak belajar melihat diri mereka di dalam konteks lingkungannya.

\section{KESIMPULAN}

Perubahan visual dari pemukiman Wonosari menjadi Kampung Pelangi, disambut positif oleh warga setempat karena berdampak pada beberapa perbaikan antara lain: pertama pada perbaikan wajah kampung. Respon warga terhadap perubahan visual adalah, warna-warni kampung telah menciptakan nuansa yang cerah pada lingkungan dan mendorong warga untuk selalu menjaga kebersihan dan keindahan kampung. Kedua terjadi perbaikan ekonomi, ketika kampung banyak dikunjungi wisatawan sehingga warga berpeluang untuk membuka usaha seperti warung dan menjual souvenir. Ketiga, warna-warni kampung selain menarik wisatawan juga menarik stakeholder dari berbagai lembaga untuk terus mendorong kemajuan Kampung Pelangi sebagai kawasan wisata, dalam bentuk pelatihan dan perbaikan lingkungan. Karakteristik tempat meliputi faktor fisik, faktor ekonomi, dan faktor sosial mempengaruhi penilaian warga terhadap tempat serta keterikatannya terhadap tempat (Lestari dan Sumabrata, 2018). 
Selain sisi positif yang telah terjadi di Kampung Pelangi, masih ada ruang yang perlu untuk ditingkatkan. Perbaikan dan pengembangan di Kampung Pelangi masih sangat tergantung pada faktor eksternal atau tingginya keterlibatan external stakeholder dalam menciptakan keberlanjutan. Dalam rangka menciptakan City Branding atau Place Branding memerlukan tiga atribut utama yaitu: Citra (image), keunikan (uniqueness) dan keaslian (authenticity). Dalam konteks Kampung Pelangi, atribut pertama yaitu citra (image) warna-warni Kampung Pelangi saat ini dapat diartikan sebagai ekspresi keceriaan dan keberagaman, walaupun citra ini dapat berubah seiring dengan waktu dan berbagai faktor yang melatarinya. Namun warna-warni saja tidak cukup untuk menciptakan suatu keberlanjutan yang lebih menyeluruh dalam lingkup sosio kultural serta mendorong upaya-upaya untuk menciptakan keberlanjutan lingkungan hidup yang lebih baik. Maka, diperlukan upaya-upaya untuk menciptakan uniqueness dan authenticity atau kekhasan Kampung Pelangi yang berbeda dengan tempat lain. Upayaupaya pemberdayaan yang dilakukan oleh berbagai stakeholder diharapkan dapat mendorong perkembangan komunitas-komunitas kreatif warga serta menggali nilainilai tradisional atau berbagai bentuk warisan budaya yang ada. Perwujudan identitas tempat memerlukan proses kolaboratif antara perancang dan masyarakat setempat, di mana latar budaya lokal, aspirasi kolektif dan bagaimana masyarakat menyelesaikan persoalan masyarakat dan lingkungannya merupakan faktor-faktor yang perlu dipertimbangkan (Kavaratzis, 2015).

Tahap penelitian selanjutnya fokus pada bentuk pendekatan place branding yang bersifat kolaboratif dan partisipatif. Proses perwujudan identitas dan konstruksi makna suatu tempat dilakukan melalui proses dialog antara pemangku kepentingan. Seperti yang diungkap oleh Hereźniak bahwa pendekatan place branding yang berpusat pada masyarakat, memerlukan pemahaman tentang konstruksi makna oleh warga setempat (Hereźniak, 2017). Konstruksi makna dipersepsikan dan diekspresikan melalui semangat komunal dan kolektif, berdasarkan pengalaman bersama, berdasarkan hubungan sosial yang ada di tempat yang dipengaruhi oleh sejarah, budaya, lanskap serta faktor ekonomi. Pendekatan perwujudan place branding melalui pendekatan co-creation dengan mengacu pada transformasi potensi warga.

\section{DAFTAR PUSTAKA}

Adiwibawa, B. A. P., \& Prabowo, D. P. (2018). Karakter Fasad Bangunan Ikonik Kota sebagai Alternatif Desain Identitas Kota Semarang. ANDHARUPA: Jurnal Desain Komunikasi Visual \& Multimedia, 2(01), 23-32.

Adler, P. S. (2009). The Oxford handbook of sociology and organization studies: Classical foundations. Oxford: Oxford University Press.

Altman,I. dan Low, S.M. (1992). Place attachment. New York: Plenum.

Arnheim, R. (1977). Visual thinking. Berkeley, Calif: University of California Press.Green, A, Grace, D, Perkins, H (2016). City Branding Research and Practice: An Integrative Review. The Journal of Brand Management Volume 23, Issue 3, 252-272. 
Hernandez, B. ; Hidlago, M.C. dan Ruiz, C., (2014). Theoretical and methodoligical aspects of research on place attachment. Place attachment: Advances in theory, methods and applications, 125-134.

Hereźniak, M. (2017). Place Branding and Citizen Involvement: Participatory Approach to Building and Managing City Brands. Interdisciplinary Political and Cultural Journal Vol.19, No. 1.

Hornskov, S.B. (2007). On the management of authenticity: Culture in the place branding of Oresund. Place Branding and Public Diplomacy, 3(4), 317-331.

Jorgensen, B.s., dan Stedman, R.C. (2001) Sense of Place as an attitude: Lakeshore owners' attitudes toward their properties. Journal of Environmental Psychology 21, 233-248.

Kaltenborn, B. P.( 1998). Effects of sense of place on responses to environmenta I impacts. A study among residents in Svalbard in the Norwegian high Arctic. Applied Geography 18 (2), 169-189.

Kavaratzis, M. (2004). From city marketing to city branding: Towards a theoretical framework for developing city brands. Place Branding. 1(1), 58-73.

Kavaratzis, M. (2015). Place branding scholars and practitioners: "Strangers in the night"? Journal of Place Management and Development 8(3): 266-270.

Kavaratzis, M., Warnaby, G., \& Ashworth, G. J. (2015). Rethinking place branding: Comprehensive brand development for cities and regions.

Kotler et.all (2004). Where is place branding heading? Place Branding, Henry Stewart Publications 1, 12-35.

Lestari, W.M, dan J Sumabrata, J.(2018). The influencing factors on place attachment in neighborhood of Kampung Melayu. IOP Conf. Ser.: Earth Environ. Sci.

Manzo, L. C. dan Devine, W. P. (2014). Place attachment: Advances in theory, methods and applications.

Proshansky, H.M., Fabian, A.K. dan Kaminoff, R. (1983). Place Identity. Journal of Environmental Psychology, 3, 57-83.

Ram, Y.; Björk, P. dan Weidenfeld, A. (2016). Authenticity and Place Attachment of Major Visitor Attractions. Tourism Management, 52, 110-122.

Riza, M.; Doratli, N. dan Fasli, M. (2011). City Branding and Identity. In: Asia Pacific International Conference on Environment-Behaviour Studies, Salamis Bay Conti Resort Hotel, 7-9 December 2011. Eastern Mediterranean University, Famagusta, North Cyprus.

Sandström, S. (2007). Explaining the obvious : a theory of visual images as cognitive structures. Lund University.

Saraswati, D.R dan Nestri M.D. (2017). Kajian Estetika Lingkungan Kampung Pelangi Studi Kasus: Jalan Lingkungan Kampung Pelangi Gg. VI. In: Seminar Nasional Arsitektur Populis dan Tantangan Indonesia Masa Kini 2017. Semarang, Jawa Tengah Indonesia September 2017. Unika Soegijapranata: Semarang.

Skinner, H. (2008). The emergence and development of place marketing's confused identity. Journal of Marketing Management, 24(9/10), 915-928.

Smaldone, D., Harris, C. dan Sanyal, N. (2008) The role of time in developing placce meanings. Journal of leisure resaerch, 40 (4), 479-504. 
Stern, B.B. and Schroeder, J.E. (1994), "Interpretive methodology from art and literary criticism: a humanistic approach to advertising imagery", European Journal of Marketing, Vol. 28 No. 8/9, pp. 114-32.

Stokols, D. dan Shumaker, S.A. (1981). People in places: A transactional view of settings. J. Harvey (ed.), Cognition, social behavio and the environment (p441-448). Hilsdale, NJ: Erlbaum.

Stubbs, J. and Warnaby, G. (2015). Rethinking place branding from a practice perspective: Working with stakeholders. dalam: M. Kavaratzis, G. Warnaby and G.J. Ashworth Rethinking Place Branding. Netherlands: Springer, pp. 101-118.

Tajfel, H. (1978). Differentiation between social groups: Studies in intergroup relations. London, England: Academic Press.

Vignoles, V.L. (2017) Identity: Personal and Social. Oxford handbook of positive psychology New York: Oxford University Press.

Zhang, L. Dan Zhao, S. (2009). City Branding and the Olympic Effect: A Case Study of Beijing. Cities 10.1016. 26. 245-254.

Sumber internet:

dictionary.com (2020) URL: https://www.dictionary.com/browse/branding [Diakses pada 17 Januari 2020]

businessdictionary.com (2020) URL: http://www.businessdictionary.com/definition/ visual-identity.html [diakses pada 17 Januari 2020] 